\title{
Ovarian follicular expression of mRNA encoding the type I IGF receptor and IGF-binding protein-2 in sheep following five days of nutritional supplementation with glucose, glucosamine or lupins
}

\author{
M Muñoz-Gutiérrez ${ }^{1,3}$, D Blache ${ }^{2}$, G B Martin² and R J Scaramuzzi ${ }^{1}$ \\ ${ }^{1}$ Department of Veterinary Basic Sciences, Royal Veterinary College, Royal College Street, London NW1 OTU, \\ UK, ${ }^{2}$ School of Animal Biology, University of Western Australia, Crawley 6009, Western Australia, Australia \\ and ${ }^{3}$ Departamento de Biología de la Reproducción, Universidad Autónoma Metropolitana Iztapalapa, \\ 09340 Mexico City, Mexico
}

Correspondence should be addressed to M Muñoz-Gutiérrez, Department of Veterinary Basic Sciences, Royal Veterinary College, University of London, Royal College Street, London NW1 OTU, UK; Email: mmunoz@rvc.ac.uk

\begin{abstract}
The IGF system is associated with ovarian folliculogenesis. The effect of the IGFs mediated through the type I receptor (IGFIR) and IGF-binding protein-2 (IGFBP-2), is to regulate the growth and atresia of follicles. To test if the mRNAs for IGF-IR and IGFBP-2 are differentially regulated in the follicle we used nutritional treatments that stimulate folliculogenesis and measured, by in situ hybridisation, their mRNAs expression. Groups of five anoestrous Merino ewes were fed wheat straw (control) or the control diet supplemented with lupins $(500 \mathrm{~g} / \mathrm{day})$. Other ewes were fed the control diet and infused with glucose $(50 \mathrm{mmol} / \mathrm{h})$ or with glucosamine $(3.5 \mathrm{mmol} / \mathrm{h})$. Intravaginal progestagen sponges were inserted for 12 days, and nutritional treatments were started 5 days before progestagen removal. Follicular development was studied after an artificial follicular phase, simulated by progestagen for 12 days and a regime of $\mathrm{GnRH}$ pulses given for $36 \mathrm{~h}$ following progestagen withdrawal, when the animals were killed. The ovaries were collected and stored at $-80^{\circ} \mathrm{C}$ until sectioning at $10 \mu \mathrm{m}$. Every $25-28$ th and 29-32nd section was probed for IGF-IR and IGFBP-2 using ${ }^{35}$ S-labelled oligonucleotide probes. None of the nutritional treatments affected the number or size of follicles positive for IGF-IR, but glucose $(P<0.001)$ and lupin $(P<0.001)$ treatments reduced the follicular concentration of $m R N A$. The nutritional treatments all increased the number of follicles positive for IGFBP-2 $(P<0.05)$ and reduced their mean diameter $(P<0.05)$ and with the exception of lupin feeding, the concentration of mRNA $(P<0.05)$. The results show that all treatments affected the intrafollicular IGF system and suggest that IGF-IR and IGFBP-2 are nutritionally regulated in the follicle. However, the effects of treatments were variable and suggest the existence of multiple regulatory mechanisms that allow for normal variation in composition and balance of the ruminant diet.

Reproduction (2004) 128 747-756
\end{abstract}

\section{Introduction}

The relationship between nutrition and reproduction has been of interest to reproductive physiologists since the end of the 19th century (Heape 1899, Marshall 1904, 1905). Much of this research has focused on the effects of nutrition on ovulation rate and twinning (Clark 1934, Lindsay 1983, Lindsay et al. 1991, L'Anson et al. 1994, Robinson 1996). There is now a broad consensus that the effects of nutrition on ovulation rate and twinning are mediated by an effect of nutrition on folliculogenesis and that this effect can act at more than one level in the hypothalamo-pituitary-ovarian axis (Landau et al. 1995, Boukhliq et al. 1996, Robinson
1996, Rhind \& McNeilly 1998, Armstrong et al. 2002, Gong 2002). Severe undernutrition suppresses the secretion of gonadotrophin-releasing hormone $(\mathrm{GnRH})$ interfering with the normal ovarian cyclicity leading to the inhibition of folliculogenesis, the failure of ovulation and increasing the possibility of infertility (Boukhliq et al. 1996, Cameron 1996, Robinson 1996, Kafi \& McGowan 1997, Nottle et al. 1997, Bossis et al. 1999). However, increased nutrition can stimulate folliculogenesis by a direct action on the follicle that is largely independent of either luteinising hormone $(\mathrm{LH})$ or follicle-stimulating hormone $(\mathrm{FSH})$ secretion (Ritar \& Adams 1988). The flushing effect in 
ewes, whereby increased feeding stimulates folliculogenesis, ovulation rate and twinning, is an example of this phenomenon (Leury et al. 1990, Scaramuzzi \& Campbell 1990, Scaramuzzi et al. 1993, Hinch \& Roelofs 1986).

The ewe's genetic potential for folliculogenesis is particularly sensitive to environmental modification. Thus the ewe is capable of a wide variation in both ovulation rate and litter size and nutrition is perhaps the most significant environmental factor affecting these (Martin et al. 1992). Thus the ewe is an excellent model to study nutritional influences on folliculogenesis. The mechanism that links nutrition to folliculogenesis is probably mediated by the changing concentrations of blood metabolites and/or nutrients acting directly on the follicle (Scaramuzzi \& Campbell 1990, Scaramuzzi et al. 1993, Downing et al. 1995a-c, Gong 2002).

In recent years considerable effort has been expended in attempts to identify the metabolic and nutritional factors linking nutrition with folliculogenesis. The insulin-like growth factor (IGF) system is a likely candidate system that has not been extensively investigated in the sheep, although there are strong grounds for expecting that the system is involved in the nutritional regulation of ovine folliculogenesis (Monget \& Martin 1997). First, hepatic production of IGF-I is itself nutritionally regulated (Renaville et al. 2002) and secondly IGF-I has a stimulatory effect on granulosa cells (Maggofin \& Erickson 1994, Monniaux et al. 1994, Campbell et al. 1995, Khalid \& Haresing 1996, Deaver \& Bryan 1999). In sheep it stimulates oestradiol production (Scaramuzzi et al. 1999) and in sheep and cattle it interacts with insulin at physiological levels to influence both cellular proliferation and oestradiol production (Monniaux et al. 1994, Campbell et al. 1995, Schams et al. 1999, Vendola et al. 1999, Gong 2002). Physiological concentrations of IGF-I enhance FSH-stimulated steroidogenesis, $\mathrm{LH}$ receptor induction and the deposition of proteoglycans. Granulosa cells also synthesise IGF-I-binding proteins that participate in regulating local responses to IGFs and the availability of follicular IGFs depends on IGF-binding proteins (IGFBPs) and between them they modulate folliculogenesis (Monget et al. 1993, 1996, 2002, Monniaux et al. 1994, Spicer et al. 1995). This experiment set out to test the hypothesis that the intrafollicular IGF system is a mediator of the effect of nutrition on follicular development of the ewe. We did this by determining the effects of nutrition on the patterns of mRNA expression for components of the IGF system in ovine follicles. In this paper, as part of an ongoing study of the nutritional regulation of the IGF system in the follicle, we describe the pattern of mRNA expression for the type I IGF receptor (IGF-IR) and IGFBP-2 in ewes given nutritional treatments that stimulate folliculogenesis. The treatments we chose were the infusion of glucose and supplementation with lupin grain, both of which increase ovulation rate in sheep (Downing et al. 1995a,c, Muñoz-Gutiérrez et al. 2002). In addition we also tested a more speculative treatment (glucosamine infusion) because there is evidence to suggest that glucosamine is an essential component of energy-sensing pathways (the hexosamine pathway) in muscle (Wang et al. 1998) and we reasoned that it might have a similar role in the follicle.

\section{Material and Methods}

\section{Animals and treatments}

Twenty-one anoestrous Merino ewes were treated for 12 days with medroxyprogesterone sponges (Repromap; Upjohn, Rydalmare, NSW, Australia). At the same time, the animals were allocated randomly to one of four treatment groups: (i) basal straw diet plus jugular infusion of saline (control group, $n=5$ ); (ii) basal straw diet plus $50 \mathrm{mmol}$ glucose/h by jugular infusion $(n=5)$; (iii) basal straw diet plus $500 \mathrm{~g}$ lupin grain/day $(n=6)$; and (iv) basal straw diet plus $3.5 \mathrm{mmol}$ glucosamine/h by jugular infusion $(n=5)$. The nutritional treatments lasted for $120 \mathrm{~h}$ and ended at the time of sponge removal. The day before the experiment started, bilateral jugular venous cannulae were inserted under xylocaine-induced local anaesthesia. One catheter was used exclusively for infusions and the other for collecting blood samples. An artificial follicular phase to stimulate normal follicular development was induced using $\mathrm{GnRH}$. Intravaginal progestagen sponges (Chronogest; Intervet Australia Pty Ltd, Lane Cove, NSW, Australia) were inserted into anoestrous ewes and left in place for 12 days. Starting at sponge removal, each ewe was treated with a regime of i.v. pulses of GnRH (Sigma, St Louis, MO, USA). The pulses were administered in three stages: $500 \mathrm{ng}$ every $4 \mathrm{~h}$ from 0 to $12 \mathrm{~h} ; 250 \mathrm{ng}$ every $2 \mathrm{~h}$ from 14 to $24 \mathrm{~h}$; and $200 \mathrm{ng}$ every $1 \mathrm{~h}$ from 25 to $36 \mathrm{~h}$. The animals were then killed with an overdose $(5-6 \mathrm{~g})$ of i.v. pentobarbital $156 \mathrm{~h}$ after starting nutritional treatments and $36 \mathrm{~h}$ after sponge removal. The ovaries were removed within $5 \mathrm{~min}$, frozen in dry ice and stored at $-80^{\circ} \mathrm{C}$ (Muñoz-Gutiérrez et al. 2002).

\section{Follicle counts}

Forty-two frozen ovaries were sectioned serially at $10 \mu \mathrm{m}$ using a cryostat at $-20^{\circ} \mathrm{C}$ and the frozen sections were used to count and measure the population of antral follicles and to measure the pattern of mRNA expression for aromatase. These data have been reported in a previous publication (Muñoz-Gutiérrez et al. 2002). The remaining sections were available for additional analyses and every 25th to 32 nd were selected so that all antral follicles could be examined in at least two series of sections, by in situ hybridisation (ISH) to determine the expression of the mRNAs for IGF-IR and IGFBP-2.

\section{ISH}

The follicular expression of mRNAs for IGF-IR and IGFBP2 were determined on dehydrated and fixed sections. The sections were probed with $\left[\alpha-{ }^{35} \mathrm{~S}\right] \mathrm{dATP}-$ (S) 1334; 
Amersham Pharmacia Biotech; Bucks, UK) labelled probes for IGF-IR and IGFBP-2 (sense; 45mers synthetic singlestranded oligonucleotide). The oligonucleotides (5 ng) were end-labelled using deoxynucleotidyl transferase (Promega, UK, Delta House, Chilworth Research Centre, Southampton, UK). The probe sequences were based on published cDNA sequences for IGF-IR and IGFBP-2 (Perks et al. 1995, Perks \& Wathes 1996). The IGF-IR oligonucleotide $45 \mathrm{mer}$ was synthesised using the specific sequence $5^{\prime}$-ctc acg gtc atc cgc ggc tgg aaa ctc ttc tac aac tac gcc ctg-3' (Ullrich et al. 1986, Genbank accession number NM_000875). The IGFBP-2 oligonucleotide $45 \mathrm{mer}$ was synthesised using the specific sequence $5^{\prime}$-gcg cca gcc ccg agc agg ttg cag aca atg gcg agg agc act ctg-3' (Delhanty \& Han 1992, Genbank accession number S44612).

Established ISH procedures (Perks 1994, Wathes et al. 1996, Leung 1997, Muñoz-Gutiérrez et al. 2002) were used with minor modifications. Briefly, the sections were impregnated with the reaction mixture containing labelled probe in hybridisation buffer (100000 c.p.m. per $100 \mu \mathrm{l}$ hybridisation buffer per slide) covered with a Parafilm coverslip, and incubated overnight at $49^{\circ} \mathrm{C}$. After incubation, the sections were washed at room temperature in citrate buffer $(15 \mathrm{mmol} / \mathrm{l}$ sodium chloride, $15 \mathrm{mmol} / \mathrm{l}$ sodium citrate, $\mathrm{pH} 7.0$, containing $0.2 \%(\mathrm{w} / \mathrm{v})$ sodium thiosulphate pentahydrate) in a shaking bath for $30 \mathrm{~min}$ followed by $1 \mathrm{~h}$ at $60^{\circ} \mathrm{C}$. The slides were dehydrated in a gradient of ethanol, air dried and exposed to Kodak Biomax MR-1 film for 5 days. The sense probes were used as the negative control. Sections of ovine placentome were used as positive control because there is strong expression of both IGF-IR and IGFBP-2 in this tissue (Reynolds et al. 1997).

\section{Photographic development}

The manufacturer's (LM-1; Amersham Pharmacia Biotech) instructions were followed. Briefly, dried slides were dipped into the emulsion for $5 \mathrm{~s}$ at $43{ }^{\circ} \mathrm{C}$ and allowed to dry at room temperature and then on a metal tray precooled with dry ice for $10 \mathrm{~min}$. The slides were then placed in a light-tight box with anhydrous silica gel. After 45 days of exposure, the slides were dipped into a developer (Phenisol; Ilford Limited, Ilford, Essex, UK) for 5 min and then into a stop bath of $0.5 \%$ acetic acid $(\mathrm{v} / \mathrm{v})$ for
$1 \mathrm{~min}$. The developed slides were immersed in a fixative $(47 \%(\mathrm{w} / \mathrm{v})$, sodium thiosulphate pentahydrate) and washed before counterstaining with Harris' haematoxylin and eosin (Muñoz-Gutiérrez et al. 2002).

\section{Image analysis}

After exposure, the autoradiographic images of the ovarian sections were quantified for specific labelling using an image analysis system (Seescan, Cambridge, UK) to measure the absorbance of specific areas identified in the adjacent slides. The emulsion-coated slides were also used to confirm the cellular localisation of the IGF-IR and IGFBP-2 signals. The results from the autoradiographs are expressed as arbitrary units (units of absorbance with a linear range of $0.01-2.10$ ). The non-specific counts (estimated from the sense probe) were subtracted from the total counts (estimated from the anti-sense probe) to produce a mean value for specific hybridisation in each follicle (Muñoz-Gutiérrez et al. 2002).

\section{Statistical analysis}

The total number of follicles, the number of positive follicles, the diameter of positive follicles and the relative density of expression were all analysed for treatment effects using a split-plot ANOVA. When significant effects were detected, further post-hoc tests using Tukey's test (SAS 1995) were carried out to examine specific treatment effects. The proportions of probe positive follicles between treatments were tested by the $\mathrm{Chi}^{2}$ test.

\section{Results}

One animal in the lupin-fed group had an infected uterus and persistent corpus luteum and was excluded from the results and the analysis.

\section{Ovarian IGF-IR mRNA}

All antral follicles, consisting of 1404 follicles in 40 ovaries from 20 sheep were tested for both IGF-IR and IGFBP2 mRNA expression. The number of follicles positive for IGF-IR was not affected by the treatments (Table 1). Although the glucose-infused and lupin-fed groups tended to have more follicles positive for the IGF-IR than control and glucosamine-infused ewes, the differences were not

Table 1 The number and average diameter of IGF-IR-positive follicles and IGF-IR expression (arbitrary units of absorbance) of GnRH-treated anoestrous Merino ewes infused with glucose or glucosamine, or fed a supplement of lupin grain for 5 days. Values are means \pm S.E.M. $n=5$ in each treatment.

\begin{tabular}{lccc}
\hline Treatment & $\begin{array}{c}\text { Number of IGF-IR-positive } \\
\text { follicles per ewe }\end{array}$ & $\begin{array}{c}\text { Diameter of IGF-IR-positive } \\
\text { follicles }(\mathrm{mm})\end{array}$ & $\begin{array}{c}\text { IGF-IR mRNA concentration } \\
\text { (units of absorbance) }\end{array}$ \\
\hline Control & $10.6 \pm 4.0$ & $1.8 \pm 0.13$ & $0.12 \pm 0.007^{\mathrm{a}}$ \\
Glucose infusion & $20.4 \pm 9.8$ & $1.7 \pm 0.11$ & $0.05 \pm 0.003^{\mathrm{b}}$ \\
Lupin-fed & $13.2 \pm 6.4$ & $1.57 \pm 0.13$ & $0.07 \pm 0.007^{\mathrm{b}, \mathrm{c}}$ \\
Glucosamine infusion & $10.8 \pm 9.4$ & $1.79 \pm 0.18$ & $0.10 \pm 0.016^{\mathrm{a}, \mathrm{c}}$ \\
\hline
\end{tabular}

Values with different superscripts within columns differ significantly $(P<0.001)$. 
statistically significant. There was an effect of treatment on the proportion of follicles positive for IGF-IR $(P=0.027)$. Compared with controls (23.8\%) glucose infusion had no effect $(20.0 \%)$, but lupin feeding $(17.7 \%)$ and glucosamine infusion $(16.8 \%)$ resulted in lower proportions of follicles positive for IGF-IR. The mean diameter of follicles positive for IGF-IR was not affected (Table 1).
The expression of mRNA for IGF-IR was localised in the granulosa and theca cell layers (Fig. 1) and the concentration of mRNA varied with treatment $(P=0.001$; Table 1). Control and glucosamine-infused ewes had high expression of IGF-IR and the group means were not significantly different from each other (Table 1) but they were significantly different from the groups' means (a)
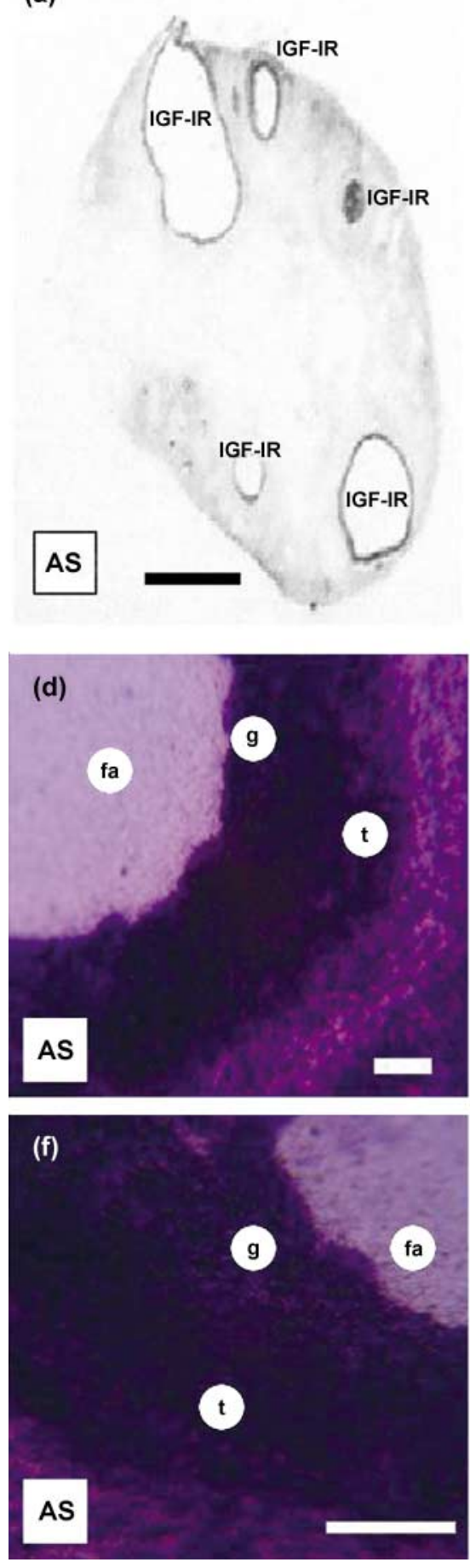

Reproduction (2004) 128 747-756 (b)
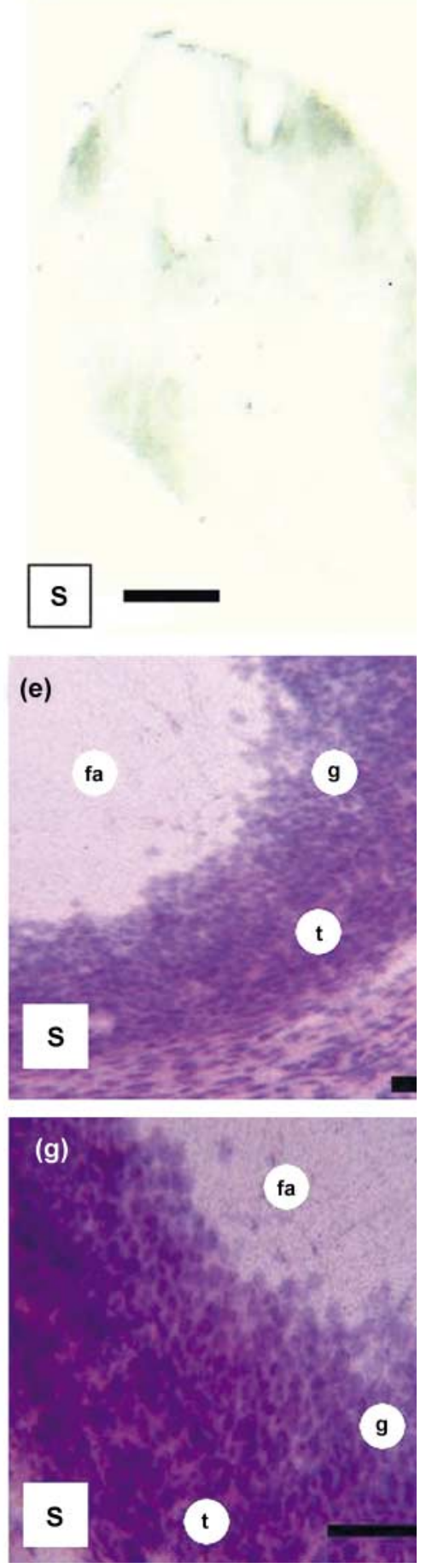

Figure 1 Antisense (AS; panels a, $d$ and $f$ ) and sense (S; panels b, e and g) autoradiographic localisation of mRNA for IGF-IR in ovaries from $\mathrm{GnRH}$-stimulated anoestrous Merino ewes. Note the intense expression of IGF-IR (panels $d$ and $f$ ) in both the granulosa (' $\mathrm{g}$ ') and theca (' $\mathrm{t}$ ') cells compared with the follicular antrum ('fa') or the ovarian stroma. Scale bars represent ( $\mathrm{a}$ and b) $2.5 \mathrm{~mm}$ and $(\mathrm{d}-\mathrm{g}) 10 \mu \mathrm{m}$. 
for the lupin-fed and glucosamine-infused ewes. The follicles from lupin-fed and glucose-infused ewes had low levels of mRNA expression for IGF-IR and again the group means were not significantly different from each other (Table 1).

\section{Ovarian IGFBP-2 expression}

The number, the percentage and the diameter of follicles positive for IGFBP-2 and the concentration of mRNA for IGFBP-2 in granulosa cells were all affected by treatments (Table 2; Fig. 2). The treated groups all had greater numbers of follicles positive for IGFBP-2 than the control group $(P=0.038$; Table 2$)$. There also were significant differences among the three treatment groups (Table 2) with the greatest in the glucose-infused group and lowest in the glucosamine-infused group. The lupin-fed group was intermediate between the glucose-infused and glucosamine-infused groups (Table 2). The glucose-infused ewes had a higher percentage $(P=0.003)$ of their antral follicle population positive for IGFBP-2 (26.70\%) than the glucosamine-infused $(16.70 \%)$, lupin-fed $(15.54 \%)$ and control $(7.18 \%)$ groups. The presence of mRNA for IGFBP-2 was only detected in the granulosa cell layer and was not seen in the thecal cell layer of any follicle (Fig. $2)$. Ewes infused with either glucose or glucosamine had significantly $(P=0.040)$ greater concentrations of mRNA IGFBP-2 in the granulosa cells than control or lupin-fed ewes (Table 2).

\section{Ovarian $P_{450}$ aromatase $m R N A, I G F-I R$ mRNA and IGFBP-2 MRNA}

This set of ovaries contained 31 aromatase-positive follicles spread across all groups and these data have been previously reported (Muñoz-Gutiérrez et al. 2002). In brief, of the 31 aromatase-positive follicles, 15 (48.3\%) were also positive for IGF-IR (Fig. 3) and their distribution was not affected by treatment $(P=0.09)$. The percentages by treatment were: control $(50.0 \%)$, glucose-infused $(40.0 \%)$, lupin-fed $(37.5 \%)$ and glucosamine-infused (44.4\%).

In contrast, the number of aromatase-positive follicles also showing IGFBP-2 expression was affected by treatment $(P=0.022)$. From 31 aromatase-positive follicles, 23 $(74.2 \%)$ were positive for IGFBP-2 (Fig. 3). These follicles were found in all treatments. The percentages by treatment were: control (100\%), glucose-infused (100\%), lupin-fed (62\%) and glucosamine-infused (44\%).

None of the treatments affected $(P=0.99)$ the number of aromatase-positive follicles that were positive for both IGF-IR and IGFBP-2 (Fig. 3). Of the 23 follicles aromatasepositive and IGFBP-2-positive only 15 were also positive for IGF-IR. The percentage of aromatase positive follicles positive for both IGF-IR and IGFBP-2 was $62.2 \%$. The percentages of follicles by treatment that were positive for all three probes were 50, 40, 40 and 50\% for control, glucose-infused, lupin-fed and glucosamineinfused respectively.

\section{Discussion}

The aim of this work was to find out if components of the ovarian IGF system are regulated by nutritional treatments known to stimulate folliculogenesis, and our findings show that both the IGF-I receptor and IGFBP-2 have differential responses to these treatments. In summary, our data show that all three treatments affected the IGF system, suggesting that both IGF-IR and IGFBP-2 nutritional regulation is probably at the level of the follicle itself. The effects of the three treatments were not identical, suggesting different mechanisms that presumably take account of natural variation in the composition (carbohydrate, free fatty acids and protein) of the ruminant diet, are operating to regulate nutritional responses in the ovine follicle.

The expression of mRNA for the IGF-IR was detected in granulosa and theca cells of antral follicles and particularly small antral follicles, confirming earlier observations (Perks et al. 1995). There was no effect of the nutritional treatments on the number or the average diameter of follicles positive for IGF-IR but there were differences in the concentration of message in the follicle wall. The infusion of glucose and the feeding of lupin grain both reduced the concentration of message compared with controls. This finding suggests that one effect of these treatments is to modify IGF-I-stimulated steroidogenesis in the follicle. The concentration of mRNA in the follicle wall was determined using quantitative densitometry on photographic images of whole ovaries on photographic film. This technique detects those follicles expressing mRNA in the follicle wall but it is

Table 2 The number and average diameter of IGFBP-2-positive follicles and IGFBP-2 expression (arbitrary units of absorbance) of GnRH-treated anoestrous Merino ewes infused with glucose or glucosamine, or fed a supplement of lupin grain for 5 days. Values are means \pm S.E.M. $n=S$ in each treatment.

\begin{tabular}{lccc}
\hline Treatment & $\begin{array}{c}\text { Number of IGFBP-2-positive } \\
\text { follicles per ewe }\end{array}$ & $\begin{array}{c}\text { Diameter of IGFBP-2-positive } \\
\text { follicles }(\mathrm{mm})\end{array}$ & $\begin{array}{c}\text { IGFBP-2 mRNA concentration } \\
\text { (units of absorbance) }\end{array}$ \\
\hline Control & $4.6 \pm 0.6^{\mathrm{a}}$ & $2.53 \pm 0.38^{\mathrm{a}}$ & $0.18 \pm 0.019^{\mathrm{a}}$ \\
Glucose infusion & $24.6 \pm 1.9^{\mathrm{b}}$ & $2.13 \pm 0.13^{\mathrm{a}}$ & $0.26 \pm 0.033^{\mathrm{b}}$ \\
Lupin-fed & $12.8 \pm 1.2^{\mathrm{c}}$ & $1.85 \pm 0.23^{\mathrm{b}}$ & $0.19 \pm 0.014^{\mathrm{a}}$ \\
Glucosamine infusion & $8.8 \pm 1.4^{\mathrm{d}}$ & $1.76 \pm 0.17^{\mathrm{b}}$ & $0.23 \pm 0.016^{\mathrm{b}}$ \\
\hline
\end{tabular}

Values with different superscripts within columns differ significantly $(P<0.05)$. 


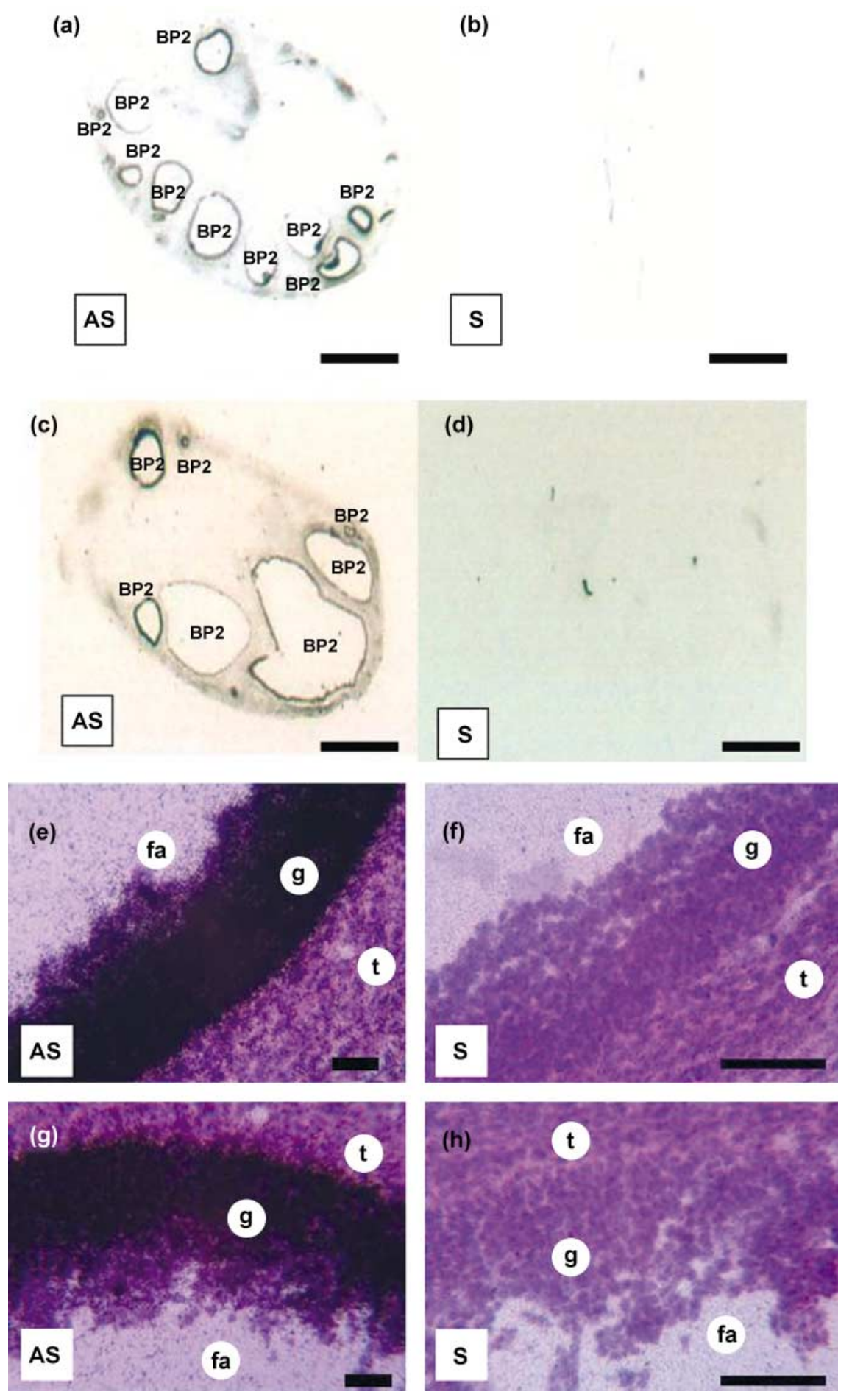

Figure 2 Antisense (AS; panels a, c, e and g) and sense ( $S$; panels $b, d$, $f$ and $h$ ) autoradiographic localisation of mRNA for IGFBP-2 in ovaries from $\mathrm{GnRH}$-stimulated anoestrous Merino ewes. Note the intense expression of IGFBP-2 (panels e and g) is confined to the granulosa cell layer (' $\mathrm{g}$ ') and expression is not seen in the theca $(' t$ '), the follicular antrum ('fa') or the ovarian stroma. Scale bars represent $(\mathrm{a}-\mathrm{d}) 2.5 \mathrm{~mm}$ and $(\mathrm{e}-\mathrm{h}) 10 \mu \mathrm{m}$. unable to differentially quantify expression from the granulosa and theca cell layers. Consequently, it is not possible to tell if the nutritional treatments affected the concentrations of mRNA in the granulosa or theca layers of the follicle.

Our interpretation of these results is that the lower concentration of IGF-IR message would lead to a reduced number of IGF-IR receptors in the plasma membrane
(Estívariz \& Ziegler 1997) and therefore reduced IGF-Istimulated steroidogenesis in the follicle. The effect of this change would be to reduce the secretion of oestradiol and negative feedback on FSH secretion leading to a transient increase in FSH secretion (Campbell 1988) and the selection of additional dominant follicles to restore the endocrine homeostasis between oestradiol and FSH. The physiological and biological consequences of this 
(a)
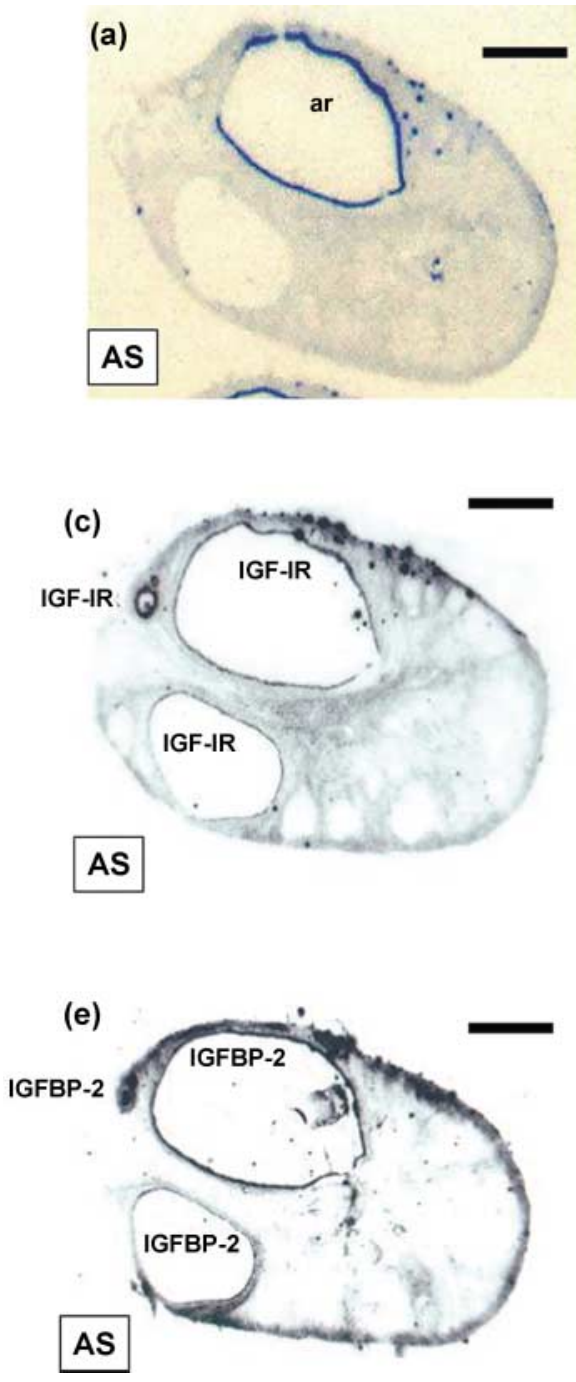
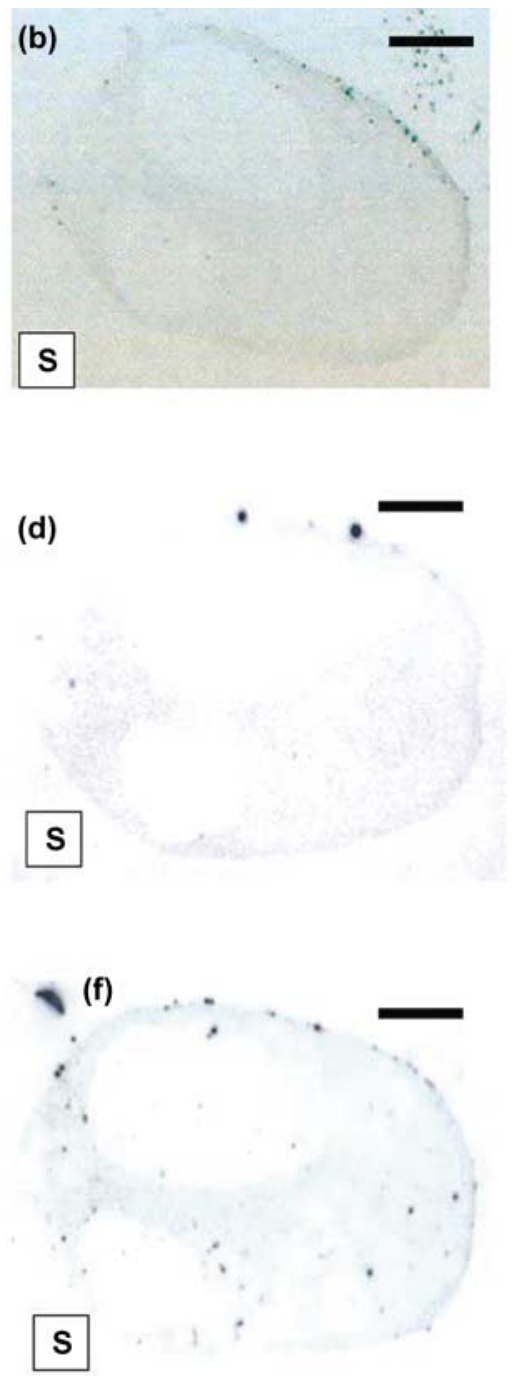

Figure 3 Antisense (AS; panels a, c and e) and sense ( $\mathrm{S}$; panels $\mathrm{b}, \mathrm{d}$ and $\mathrm{f}$ ) autoradiographic localisation of mRNA for aromatase ('ar') (a and b), IGF-IR (c and d) and IGFBP-2 ( $\mathrm{d}$ and e) in ovaries from $\mathrm{GnRH}$-stimulated anoestrous Merino ewes. Note that specific hybridisation is confined to the follicle wall of some but not all, antral follicles. The sections are sequential sections $40 \mu \mathrm{m}$ apart. The scale bars represent $2.5 \mathrm{~mm}$. effect would be an increase in ovulation rate and twinning rate (Scaramuzzi \& Campbell 1990, Scaramuzzi et al. 1993).

The cellular expression of mRNA for IGFBP-2 was determined by examining microscope slides coated with exposed photographic emulsion, under a microscope, and confirmed the expression of mRNA for IGFBP-2 in follicular granulosa cells (Besnard et al. 1996, Perks \& Wathes 1996). There were effects of all three nutritional treatments on both the pattern of follicular expression and the concentration of message within follicles (Table 2). All treatments increased the total number but not the percentage of follicles expressing the IGFBP-2 gene. These results suggest that the nutritional treatments increased the recruitment of antral follicles and that development of IGFBP-2 expression by follicles is part of the recruitment process in small follicles $(1.5-2.5 \mathrm{~mm}$ in diameter). The average diameter of follicles positive for IGFBP-2 was significantly decreased by all the nutritional treatments, again suggesting that one effect of nutritional treatments is directed towards follicles undergoing recruitment. There were also nutritionally induced differences in the concentration of mRNA for IGFBP-2 in the follicle wall. The infusion of glucose and glucosamine both increased the concentration of message compared with controls. This finding suggests that one effect of these treatments is to increase the local intrafollicular concentrations of IGFBP-2.

Since elevated intrafollicular concentrations of IGFBP-2 are associated with atresia and reduced concentrations with follicle selection (Monget \& Bondy 2000, Mazebourg et al. 2003), it is plausible to suggest that nutritionally regulated IGFBP-2 within the follicular antrum may be one mechanism by which nutrition stimulates ovulation rate in sheep. Nutritionally induced increases in the intrafollicular concentration of IGFBP-2 would be expected in follicles with increased mRNA expression and would complement nutritional effects on the IGF-IR by modifying tissue availability of IGFs in the follicle (Breier 1999, Renaville et al. 2002). This is because IGFBP-2 locally sequesters IGFs and reduces their bioavailability to the granulosa and theca cells of the follicle (Monget et al. 1993, 1996, Monget \& Monniaux 1995, Monniaux et al. 
1997, Monget \& Bondy 2000, Renaville et al. 2002, Mazebourg et al. 2003) by changing the external concentration of free IGFs in the cellular environment, by modifying cell membrane permeability, and local IGF metabolism and/or compartmentalisation in the cell (Estívariz \& Ziegler 1997), resulting in a reduction of IGFstimulated steroidogenesis in the follicle (Gong 2002).

This experiment demonstrates that all three nutritional treatments were able to modify aspects of the intrafollicular IGF system. Specifically, they show that the concentrations of mRNA for the IGF-IR and IGFBP-2 in the ovarian follicle are both differentially regulated. However, the patterns of gene expression were not identical between nutritional treatments suggesting the nutritional regulation of folliculogenesis is mediated by more than one mechanism. This is not surprising considering the varied nature of natural diets that grazing ruminant animals consume and the evolutionary significance of ovulation. The treatments we utilised were two that looked exclusively at glucogenic mechanisms (glucose and glucosamine infusion) and a third (lupin grain) that increased amino acid uptake as well as being gluconeogenic, and all of these treatments are predicted to lead to reduced IGF-stimulated steroidogenesis by the follicle. This prediction remains to be tested along with the effects of the nutritional supplements on other components of the IGF system.

The composition of the diet also affects the IGF system (Breier 1999). Nutritional protein seems to have a more significant effect on IGF-I production than nutritional energy (Renaville et al. 2002) and energy derived from carbohydrates has a more potent effect on IGF-I blood levels than energy derived from energy supplements (Estívariz \& Ziegler 1997). Some of the differential effects of diet observed in this study may therefore be associated with the nutritional treatments. Lupins are a high-quality source of both energy and protein while glucose and glucosamine are sources of energy alone. Glucose-infused ewes will have derived their energy from glucose while the energy in the glucosamine-infused ewes is derived from hepatic gluconeogenesis and fatty acid oxidation.

The fact that not all follicles positive for aromatase were also positive for IGF-IR or IGFBP-2 suggests that the intrafollicular IGF system is not essential for folliculogenesis. However, this does not preclude a regulatory role for the intrafollicular IGF system.

We conclude that at all three nutritional treatments affected the intrafollicular IGF system and that both the IGF-IR and IGFBP-2 components of the IGF system are differentially regulated by nutrition, most probably at the level of the follicle itself. Furthermore, nutritional regulation of the intra-ovarian IGF system may be responsible for nutritional effects on ovulation in sheep. The effects of the three treatments were highly variable suggesting that sheep have complex regulatory mechanisms that presumably take account of the wide variety in the composition and balance of the nutrient intake in grazing sheep.

\section{Acknowledgements}

This work was supported by grants from The Wellcome Trust, The British Council, The University of Western Australia (Distinguished visitor award for R J S) and CONACyT, Mexico. The authors would like to thank Ms $M$ Blackberry, Dr T Sharma and Dr P Celi (University of Western Australia) for their assistance.

\section{References}

Armstrong DG, Gong JG, Gardner JO, Baxter G, Hogg CO \& Webb R 2002 Steroidogenesis in bovine granulosa cells: the effect of short-term changes in dietary intake. Reproduction 123 $371-378$.

Besnard N, Pisselet C, Monniaux D, Locatelli A, Benne F, Gasser F et al. 1996 Expression of messenger ribonucleic acids of insulinlike growth factor binding protein-2, -4 and -5 in the ovine ovary localization and changes during growth and atresia of antral follicles. Biology of Reproduction 55 1356-1367.

Bossis I, Wetteman RP, Welty SD, Vizcarra JA, Spicer LJ \& Diskin G 1999 Nutritionally induced anovulation in beef heifers: ovarian and endocrine function preceding cessation of ovulation. Journal of Animal Science 77 1536-1546.

Boukhliq R, Adams NR \& Martin GB 1996 Effect of nutrition on the balance of production of ovarian and pituitary hormones in the ewes. Animal Reproduction Science 45 59-70.

Breier BH 1999 Regulation of protein and energy metabolism by the somatotropin axis. Domestic Animal Endocrinology 17 209-218.

Cameron JL 1996 Regulation of reproductive hormone secretion in primates by short-term changes in nutrition. Reviews of Reproduction 1 117-126.

Campbell BK 1988 Factors affecting ovulation rate in sheep and cattle. PhD Thesis. University of Sydney.

Campbell BK, Scaramuzzi JR \& Webb R 1995 Control of antral follicle development and selection in sheep and cattle. Journal of Reproduction and Fertility 49 335-350.

Clark RT 1934 Studies of the physiology of reproduction in sheep. 1. The ovulation rate of the ewe is affected by plane of nutrition. Anatomical Record 60 125-134.

Deaver DR \& Bryan KA 1999 Effects of exogenous somatotropin (ST) on gonadal function in ruminants and swine. Domestic Animal Endocrinology 17 287-297.

Delhanty PJ \& Han VK 1992 The characterization and expression of ovine insulin-like growth factor-binding protein-2. Journal of Molecular Endocrinology 9 31-38.

Downing JA, Joss J \& Scaramuzzi RJ 1995a Ovulation rate and the concentrations of gonadotrophins and metabolic hormones in ewes infused with glucose during the late luteal phase of the oestrous cycle. Journal of Endocrinology 146 403-410.

Downing JA, Joss J \& Scaramuzzi RJ 1995b A mixture of the branched chain amino acids, leucine, isoleucine and valine, increases ovulation rate in ewes when infused during the late luteal phase of the oestrous cycle: an effect that may be mediated by insulin. Journal of Endocrinology 145 315-323.

Downing JA, Joss J, Connell P \& Scaramuzzi RJ 1995c Ovulation rate and the concentrations of gonadotrophic and metabolic hormones in ewes fed lupin grain. Journal of Reproduction and Fertility 103 137-145.

Estívariz FC \& Ziegler TR 1997 Nutrition and the insulin-like growth factor system. Endocrine 7 65-71. 
Gong JH 2002 Influence of metabolic hormones and nutrition on ovarian follicle development in cattle: practical implications. Domestic Animal Endocrinology 23 229-241.

Heape W 1899 Abortion, barrenness, and fertility in sheep: an abstract of records obtained for the year 1896-1897. Journal of the Royal Agricultural Society (third series) 10 217-248.

Hinch GN \& Roelofs JHW 1986 Lupin feeding and insulin infusion during the late luteal phase can increase ovulation rate in sheep. Proceedings of the Australian Society for Reproductive Biology 18 43 (Abstract).

Kafi M \& McGowan MR 1997 Factors associated with variation in the superovulatory response of cattle. Animal Reproduction Science 48 137-157.

Khalid M \& Haresign W 1996 Relationships between concentrations of ovarian steroids, insulin-like growth factor-1 and IGF-binding proteins during follicular development in the ewe. Animal Reproduction Science 41 119-129.

Landau S, Bor A, Leibovich Z, Zoref Z, Nistan Z \& Madar Z 1995 The effect of ruminal starch degradability in the diet of Booroola crossbreeds ewes on induced ovulation rate and prolificacy. Animal Reproduction Science 38 97-108.

L'Anson H, Foster DL, Foxcroft GR \& Booth PJ 1994 Nutrition and reproduction. Oxford Reviews of Reproductive Biology $\mathbf{1 6}$ 239-311.

Leung ST 1997 The regulation of oxytocin receptor expression in the reproductive tract of the sheep during pregnancy. PhD Thesis. University of London.

Leury BJ, Murray PJ \& Rowe JB 1990 Effect of nutrition on the response in ovulation rate in Merino ewes following short-term lupin supplementation and insulin administration. Australian Journal of Agricultural Research 41 751-759.

Lindsay DR 1983 Nutrition and reproduction in the sheep. Proceedings of the Post-graduate Committee in Veterinary Science (The University of Sydney) 63 611-629.

Lindsay DR, Martin GB \& Williams IH 1991 Nutrition and reproduction. In Reproduction in Domesticated Animals. World Animal Science Series, pp 459-491. Ed. GJ King. Amsterdam: Elsevier Science Publishers.

Maggofin DA \& Erickson FG 1994 Control systems of theca and interstitial cells. In Molecular Biology of the Female Reproductive System, pp 39-65. Ed. KJ Findlay. New York: Academic Press.

Marshall FHA 1904 Fertility in sheep. Transactions of the Highland Agricultural Society 16 34-43.

Marshall FHA 1905 Fertility in Scottish sheep. Proceedings of the Royal Society of London B77 58-62.

Martin GB, Fisher JS \& Adams NR 1992 Environmental limitations to reproduction. Proceedings of the Australian Society of Animal Production 19 206-208.

Mazebourg S, Bondy CA, Zhou J \& Monget P 2003 The insulin-like growth factor system: a key determinant role in the growth and selection of ovarian follicles? A comparative species review. Domestic Animal Reproduction 38 247-258.

Monget P \& Monniaux D 1995 Growth factors and the control of folliculogenesis. Journal of Reproduction and Fertility 49 $321-333$.

Monget P \& Martin GB 1997 Involvement of insulin-like growth factors in the interactions between nutrition and reproduction in female mammals. Human Reproduction 12 (Suppl 1) 33-52.

Monget P \& Bondy C 2000 Importance of the IGF system in early folliculogenesis. Molecular and Cellular Endocrinology 163 89-93.

Monget P, Monniaux D, Pisselet C \& Durand P 1993 Changes in insulin-like growth factor-I (IGF-I), IGF-II and their binding proteins during growth and atresia of ovine ovarian follicles. Endocrinology $1321438-1446$.

Monget P, Besnard N, Huet C, Pisselet C \& Monniaux D 1996 Insulin-like growth factor-binding proteins and ovarian folliculogenesis. Hormone Research 45 211-217.
Monget P, Fabre S, Mulsant P, Lecerf F, Elsen JM, Mazenbourg S et al. 2002 Regulation of ovarian folliculogenesis by IGF and BMP system in domestic animals. Domestic Animal Endocrinology 23 139-154.

Monniaux D, Pisselet C \& Fontaine J 1994 Uncoupling between proliferation and differentiation of ovine granulosa cells in vitro. Journal of Endocrinology 142 497-510.

Monniaux D, Huet C, Besnard N, Clement F, Bosc M, Pisselet C et al. 1997 Follicular growth and ovarian dynamics in mammals. Journal of Reproduction and Fertility Supplement 51 3-23.

Muñoz-Gutiérrez M, Blache D, Martin GB \& Scaramuzzi RJ 2002 Folliculogenesis and ovarian expression of mRNA encoding aromatase in anoestrous sheep after 5 days of glucose or glucosamine infusion or supplementary lupin feeding. Reproduction $\mathbf{1 2 4}$ $721-731$.

Nottle BM, Kleeman DO \& Seamark RF 1997 Effects of previous undernutrition on the ovulation rate of Merino ewes supplemented with lupin grain. Animal Reproduction Science 49 29-36.

Perks MC 1994 The insulin-like growth factors in the ovine ovary. PhD Thesis. University of Bristol.

Perks CM \& Wathes DC 1996 Expression of mRNA for insulin-like growth factor binding proteins-2, -3 and -4 in the ovine ovary throughout the oestrous cycle. Journal of Endocrinology 151 241-249.

Perks CM, Denning-Kendall PA, Gilmour RS \& Wathes DC 1995 Localization of messenger ribonucleic acids for insulin-like growth factor I (IGF-I), IGF-II, and the type 1 IGF receptor in the ovine ovary throughout the estrous cycle. Endocrinology 136 $5266-5273$

Renaville R, Hammadi M \& Portetelle D 2002 Role of the somatotropic axis in the mammalian metabolism. Domestic Animal Endocrinology 23 351-360.

Reynolds TS, Stevenson KR \& Wathes DC 1997 Pregnancy-specific alterations in the expression of the insulin-like growth factor system during early placental development in the ewe. Endocrinology 138 886-897.

Rhind MS \& McNeilly AS 1998 Effects of the level of food intake on ovarian follicle number, size and steroidogenic capacity in the ewe. Animal Reproduction Science 52 131-138.

Ritar AJ \& Adams NR 1988 Increased ovulation rate, but not FSH or LH concentrations, in ewes supplemented with lupin grain. Animal Production in Australia 17 310-313.

Robinson JJ 1996 Nutrition and reproduction. Animal Reproduction Science 42 25-34.

SAS 1995 System for Windows Release 6.12. Cary, NY: SAS Institute.

Scaramuzzi RJ \& Campbell BK 1990 Physiological regulation of ovulation rate in the ewe: a new look at an old problem. In Reproductive Physiology of Merino Sheep - Concepts and Consequences, pp 71-84. Eds CM Oldham, GB Martin \& IW Purvis. Perth: School of Agriculture (Animal Science), the University of Western Australia.

Scaramuzzi RJ, Adams NR, Baird DT, Campbell BK, Downing JA, Findlay JK et al. 1993 A model for follicle selection and the determination of ovulation rate in the ewe. Reproduction, Fertility, and Development 5 459-478.

Scaramuzzi RJ, Murray JF, Downing JA \& Campbell BK 1999 The effects of exogenous growth hormone on follicular steroid secretion and ovulation rate in sheep. Domestic Animal Endocrinology 17 269-277.

Schams D, Berisha B, Kosman M, Einspanier R \& Amselgruber WM 1999 Possible role of growth hormone, IGFs and IGF-binding proteins in the regulation of ovarian function in large farm animals. Domestic Animal Reproduction 17 279-285.

Spicer JL, Echternkamp SE, Wong EA, Hammilton DT \& Vernon RK 1995 Serum hormones, follicular fluid steroid, insulin-like growth factors and their binding protein, and ovarian IGF mRNA in sheep with different ovulation rate. Journal of Animal Science $\mathbf{7 3}$ $1152-1163$. 
Ullrich A, Gray A, Tam AW, Yang-Feng T, Tsubobawa M, Collins C et al. 1986 Insulin like growth factor I receptor primary structure: comparison with insulin receptor suggests structural determinants that define functional specificity. $E M B O$ Journal $\mathbf{5}$ 2503-2512.

Vendola K, Zhou J, Wang J \& Bondy CA 1999 Androgens promote insulin-like growth factor-I and insulin-like growth factor-I receptor gene expression in the primate ovary. Human Reproduction 14 2328-2332.

Wang J, Liu R, Hawkins M, Barzilai N \& Rosseti L 1998 A nutrientsensing pathway regulates leptin gene expression in muscle and fat. Nature 393 684-688.
Wathes DC, Smith HF, Leung ST, Stevenson KR, Meier S \& Jenkin G 1996 Oxytocin receptor development in the ovine uterus and cervix throughout pregnancy and at parturition as determined by in situ hybridisation analysis. Journal of Reproduction and Fertility $10623-31$.

Received 27 July 2004

First decision 10 August 2004

Accepted 13 August 2004 